\title{
TRAJETÓRIAS SOCIAIS E PRÁTICAS POLÍTICAS NAS FRANJAS DO IMPÉRIO
}

FÁBIO KÜHN

Universidade Federal do Rio Grande do Sul

AUGUSTO DA SILVA

Universidade Federal de Sergipe

ADRIANO COMISSOLI

Universidade de Passo Fundo

\section{RESUMO}

Com base na trajetória social e nas ações políticas dos governadores nomeados para os estabelecimentos coloniais de Santa Catarina, Rio Grande de São Pedro e Colônia do Sacramento, assim como na atuação dos camaristas das vilas, os autores buscam traçar um panorama do longo processo de consolidação dos domínios portugueses no sul da América Meridional, entre finais do século XVII e princípios do século XIX. Observam que esse processo, marcado externamente por avanços e recuos na disputa com os domínios espanhóis, tem de ser compreendido, também, pelo complexo jogo de forças e interesses internos travados entre o poder monárquico português e o poder dos grupos locais.

\section{ABSTRACT}

Based upon the social life and political actions by the governors nominated to the colonial areas of Santa Catarina, Rio Grande de São Pedro and Colônia do Sacramento, as well as the "vereadores", the authors of this article try to present a broad overview of the long process of consolidation of the Portuguese dominions in southern America, between the end of XVII century and the beginning of the XIX. It is observed that this process was deeply influenced by the disputes with the Spanish crown, but also by the complex set of interests and intern conflicts between the Portuguese crown and the local powers.
PALAVRAS-CHAVE: América portuguesa; Brasil colônia; poderes locais.
KEYWORDS: Portuguese America; Colonial Brazil; local powers. 
O período compreendido desde o final do século XVII até o início do século XIX foi o momento no qual a disputada região do extremo sul da América foi incorporada à monarquia pluricontinental lusitana. Esse processo envolveu uma acirrada concorrência frente à Coroa espanhola tanto quanto uma relação tumultuada entre 0 rei português e seus agentes, fossem os nomeados para os cargos ditos centrais, fossem os representantes das elites locais encontrados nas diversas Câmaras municipais meridionais. Discutem-se aqui algumas trajetórias de governadores das capitanias do Rio Grande de São Pedro e de Santa Catarina, bem como da praça da Colônia do Sacramento, mas igualmente práticas promovidas pelos camaristas, muitos deles envolvidos com o povoamento espontâneo da região e representantes dos estratos dominantes das comunidades.

A ocupação do território meridional da América portuguesa consistiu em um misto de ações autônomas de correntes migratórias e de iniciativas patrocinadas pela Coroa. Segundo Dauril Alden, o interesse português no extremo sul teve inicialmente alcance local, passando a regional numa segunda fase e, finalmente, imperial. ${ }^{1}$ Decorre daí o caráter heterogêneo das práticas políticas, que progressivamente se direcionaram a uma formalização dada pela maior presença de elementos da administração central, o que acarretou, em última análise, um esvaziamento da instituição camarária em favor de ofícios administrativos mais diretamente ligados ao poder central. Conheçamos um pouco dessa evolução.

\section{A Colônia do Sacramento: uma praça portuguesa no rio da Prata}

Em 1680, Portugal fundava uma colônia estrategicamente situada na frente de Buenos Aires, na outra margem do rio da Prata, em terras da atual República Oriental do Uruguai. A fundação da Colônia do Sacramento pautavase por dois objetivos principais: estabelecer o comércio com terras espanholas legal e ilegal - abocanhando um quinhão da prata potosina e criar um posto avançado permanente de ocupação portuguesa. Na prática, tratava-se de um empreendimento patrocinado por grandes comerciantes fluminenses, interessados na troca de mercadorias e escravos pelo minério. ${ }^{2} \mathrm{~A}$ fundação da praça ocorreu sob a liderança de Dom Manuel Lobo, governador do Rio de Janeiro, que se tornou seu primeiro administrador. $O$ ato de ocupação territorial provocou reação imediata dos espanhóis, de modo que, na prática, os portugueses somente conseguiram se estabelecer no estuário por pouco mais

\footnotetext{
${ }^{1}$ ALDEN, Dauril. Royal Government in Colonial Brazil. Berkeley. Los Angeles: University of California Press, 1968, p. 50.

2 SAMPAIO, Antônio C. J. Na Encruzilhada do Império: hierarquias sociais e conjunturas econômicas no Rio de Janeiro (c. 1650-c.1750). Rio de Janeiro: Arquivo Nacional, 2003, p. 146147.
} 
de seis meses. Porém, já no ano seguinte, com o Tratado Provisional (07.05.1681), a Colônia do Sacramento voltava a ser lusitana. ${ }^{3}$

Em 1683, após o restabelecimento da praça ao domínio dos Bragança, o novo governador do Rio de Janeiro, Duarte Teixeira, enviou tropas, armamentos e povoadores, reabilitando a fortaleza. Iniciou-se um período de pouco mais de duas décadas em que a povoação teve certo desenvolvimento, com base no comércio de couro e na produção tritícola. Esse período foi definido pela historiografia como o do "tráfico dos governadores" pelo destaque que esses obtiveram em animar as atividades comerciais do enclave platino. ${ }^{4}$ Assim se sucedeu na administração da praça após a segunda fundação, a principiar por Cristóvão Ornelas de Abreu (1683-1689), acusado de beneficiarse do contrabando com os castelhanos de Buenos Aires. ${ }^{5}$ Seu sucessor, Francisco Naper de Lancastre (1689-1699), teve de enfrentar uma conjuntura de restrições aos contatos comerciais com os vizinhos espanhóis, mas no governo de Sebastião da Veiga Cabral $(1699-1705)^{6}$ os esforços no sentido do desenvolvimento do comércio ilícito ganharam renovadas proporções, somente sendo interrompidos com a nova ocupação castelhana da Colônia nos princípios de 1705, decorrente da conjuntura política da Guerra da Sucessão espanhola. ${ }^{7}$ A morte de Carlos II levou a mudanças na política de Madri e os portugueses novamente foram expulsos do estuário do Prata.

Porém, nas negociações de paz havidas após a guerra, outra vez o território foi recuperado ${ }^{8}$, permitindo à Colônia atingir seu ápice durante o longo reinado de $D$. João $V$, não obstante um decênio de inatividade portuguesa nas margens do Prata. Com a terceira fundação da Colônia, começava a fase de "colonização dirigida", marcada pela nomeação de Manuel Gomes Barbosa (1715-1722) como governador. ${ }^{9}$ Contra a administração do governador Barbosa pesaram duras acusações, entre elas as denúncias de particulares sobre o monopólio do acesso aos recursos da campanha e ao comércio com o Rio de

\footnotetext{
3 PRADO, Fabrício Pereira. Colônia do Sacramento: o extremo sul da América Portuguesa. Porto Alegre, F.P. Prado, 2002, p. 91-93; MONTEIRO, Jonathas da Costa Rego. A Colônia do Sacramento, 1680-1777. Porto Alegre: Livraria do Globo, 1937, p. 92 e 97.

4 JUMAR, Fernando A. Le commerce atlantique au Rio de la Plata (1680-1778). Villeneuve d'Ascq: Presses Universitaires du Septentrion, 2000, p. 222; PRADO, op. cit., p. 92.

${ }^{5}$ POSSAMAI, Paulo. A vida quotidiana na Colônia do Sacramento - Um bastião português em terras do futuro Uruguai. Lisboa: Editora Livros do Brasil, 2006, p. 342-345.

${ }^{6}$ SOUZA, Laura de Mello e. Os motivos escusos: Sebastião da Veiga Cabral. In: O Sol e a Sombra. Política e administração na América Portuguesa do século XVIII. São Paulo: Companhia das Letras, 2006, p. 253-283.

7 ALMEIDA, Luís Ferrand de. A Colônia do Sacramento na época da Sucessão de Espanha. Coimbra: Faculdade de Letras da Universidade de Coimbra 1973, p. 283-288.

${ }^{8}$ Através do artigo $6^{\circ}$ do Tratado de Paz e Amizade, assinado em Utrecht em 06 de fevereiro de 1715, o monarca espanhol Felipe $V$ devolvia formalmente o território da Colônia ao rei de Portugal.

${ }^{9} \mathrm{Em} \mathrm{1715}$, através de carta de lei, D. João $\mathrm{V}$ ordenava que o governador da praça de Santos, Manuel Gomes Barbosa, tomasse posse e governasse a Nova Colônia do Sacramento. Ver AHU - Colônia do Sacramento, cx. 1, doc. 35. No entanto, somente em 22 de outubro de 1716, o novo governador chegaria naquela praça, retomando a posse do território. Cf. Consulta do Conselho Ultramarino (13.08.1717) In: Documentos Históricos, Rio de Janeiro: Biblioteca Nacional/Divisão de Obras Raras e Publicações, vol. XCVII, 1952, p. 58-59.
} 
Janeiro. Imputavam-Ihe extorquir dinheiro pelas terras que deveria dar gratuitamente aos povoadores e de aproveitar-se das mulheres dos lavradores, fatos que aumentaram as deserções de colonos enviados à região. ${ }^{10}$

Os planos espanhóis de contenção dos portugueses aos limites da cidadela logo se frustraram, pois a Colônia entrou numa fase de esplendor econômico e social que correspondeu aproximadamente ao longo comando de Antônio Pedro de Vasconcelos (1722-1749). Esse recebera a missão de modificar a relação da autoridade régia com as elites locais, visando promover o crescimento do comércio e da povoação na Colônia platina. De fato, Vasconcelos encabeçaria uma poderosa rede de poder e negócios. Como membros dessa constavam indivíduos de destaque na praça: o sargento-mor de infantaria Manuel Botelho de Lacerda, homem de negócio e juiz da Alfândega; o comerciante inglês João Burrish, que era casado com uma filha de Botelho de Lacerda; e os almoxarifes da Fazenda Real José da Costa Pereira e Manuel Pereira do Lago, ambos capitães de ordenanças e negociantes. Progressivamente, o governador enraizou interesses e alianças com os poderosos locais, ao ponto que no final da sua administração eram quase imperceptíveis as diferenças entre os envolvimentos da autoridade externa e das elites locais. ${ }^{11}$ Nesse meio tempo, a despeito dos reiterados pedidos de seus moradores, a Colônia do Sacramento não se elevara à vila, permanecendo como uma praça comercial sem representação local até sua passagem definitiva ao controle espanhol em $1777 .^{12}$

O governador subsequente, Luís Garcia de Bivar, seguiu de perto a política de Vasconcelos. Novamente, facções da elite local forjaram alianças com o representante do poder régio, único expediente de manifestação política institucional que era possível na Colônia. Essa rede envolvia, além de Bivar, o irmão de Manuel Botelho de Lacerda e ainda o governador de Buenos Aires, José de Andonaegui. ${ }^{13}$ Os excluídos da mesma rede, "um bando de mercadores" liderados por Domingos Fernandes de Oliveira, não ficaram de mãos atadas e retaliaram o governador publicando, em 1754, uns "capítulos escandalosos e infamatórios" acusando Bivar de toda sorte de irregularidades. $\mathrm{Na}$ sua defesa, diria o governador que "culparam-me de ambicioso e de fraudador da Fazenda de S.M.", mas "todo este povo sabe que não faço negócio algum, e que os meus criados estão pobres". ${ }^{14}$ Seja como for, Bivar parece mesmo ter se fixado em Sacramento, sendo um dos poucos governadores a morrer na praça.

Com o Tratado de Madri e a nova política implementada pelo Secretário de Estado Sebastião José de Carvalho e Melo, as realidades da Colônia do

\footnotetext{
${ }^{10}$ PRADO, op. cit. p. 175; POSSAMAI, op. cit.., p. 255 e 263.

${ }^{11}$ PRADO, op. cit., p. 175-178.

12 "É importante ressaltar que juridicamente Sacramento era um presídio, uma praça militar e comercial, jamais alcançando a condição de vila. Dessa forma, não houve na Colônia uma Câmara (...). A autoridade do Governador centralizava o poder na Colônia. (...) Enfim, a ausência da câmara garantia a forte influência de parte dos grupos locais - especialmente os vinculados ao governador." Idem, ibidem. p. 106.

${ }^{13}$ Idem, ibidem. p. 182 e 184.

${ }^{14}$ AHU-Colônia do Sacramento. Cx. 5, doc. 480: Ofício do governador Luís Garcia Bivar ao secretário Diogo de Mendonça Corte Real, c. 1754.
} 
Sacramento e do estuário platino sofreriam profundas mudanças, tendo em conta a aceleração do povoamento do litoral de Santa Catarina e, principalmente, do Rio Grande de São Pedro. ${ }^{15}$ Diante da desconfiança do valido de Dom José I em relação às possibilidades de execução do tratado de limites, a cidadela platina passou a sofrer os prejuízos das opções decididas em Lisboa. Em face à dificuldade de manutenção da Colônia, Lisboa modificava sua geopolítica, pautando-a agora pela ocupação efetiva da terra, em curso desde a vila de Curitiba, mas igualmente pelo litoral catarinense e nos Campos de Viamão. Abandonava-se a opção por enclaves como Sacramento, estimulando a ocupação contínua do território ao aproveitar-se do movimento iniciado pelos paulistas e duplicado pelos lagunenses. ${ }^{16}$

Paulatinamente, preterida por Santa Catarina e pelo Rio Grande, a Colônia começou a declinar. Não por acaso os governadores dessa última fase (1760-1777) passaram maus bocados, como no caso de Vicente da Silva da Fonseca, que capitulou diante das forças espanholas em 1762, perda que Ihe custou a morte na prisão do Limoeiro. ${ }^{17}$ Da mesma forma, o último governador da Colônia, Francisco José da Rocha, ao sofrer derrota frente ao ataque espanhol de 1777, acabou degredado em Angola em total desgraça por supostamente não oferecer resistência. ${ }^{18}$ Nenhum desses governantes saiu incólume dessa fase agitada da praça platina, na qual nem mesmo a religião parecia oferecer alguma segurança: em uma denúncia feita pelo comissário do Santo Ofício, em 1773, o governador Pedro José Soares de Figueiredo Sarmento foi duramente criticado, pois "há dous anos não ouve missa, nem tem cumprido com o preceito da quaresma, com notável publicidade, e geral escândalo". Da mesma sorte, "não ajoelhava quando o sacerdote passava por diante dele com o Santíssimo Sacramento nas mãos para a mesa da comunhão". Esses procedimentos o faziam "suspeito na fé" pelo agente inquisitorial, autor da denúncia. ${ }^{19}$ Não obstante a grave acusação, Sarmento permaneceria no seu cargo até 1775 , quando a sorte da Colônia já estava, de alguma forma, selada.

\footnotetext{
15 Processo que Dauril Alden classificou como "fechamento da lacuna" (closing the gap). ALDEN, Dauril. Royal Government in Colonial Brazil. Berkeley e Los Angeles: University of California Press, 1968, p. 71-82.

${ }^{16}$ Tal política pautava-se pelo princípio do uti possidetis e alcançaria sua consagração com a assinatura do Tratado de Madri em 1750. OSÓRIO, Helen. Apropriação da Terra no Rio Grande de São Pedro e a Formação do Espaço Platino. Porto Alegre: Dissertação de Mestrado, PPG em História/UFRGS, 1990, p. 87-89.

${ }^{17}$ A descrição mais detalhada da capitulação da praça consta na História Topográfica de Simão Pereira de Sá, p. 165-192.

${ }^{18}$ LAMEGO, Alberto. "O último governador da Colônia do Sacramento: Francisco José da Rocha" in: Revista de Philologia e de história, II, Rio de Janeiro, 1933, p. 212-225.

${ }^{19}$ ANTT, Inquisição de Lisboa, Cadernos do Promotor, no 129, fl. 160. Para a atuação do Santo Ofício na Colônia, ver POSSAMAI, op.cit., p. 315-317.
} 


\section{Dos sertões ao litoral e rumo ao sul: a ilha de Santa Catarina e o continente de São Pedro}

Enquanto em Colônia a supremacia dos governadores era evidente, a ocupação do território meridional, a partir do sertão de Curitiba, mostrava-se mais complexa, oferecendo bastante espaço às lideranças locais. Na segunda metade do século XVII, famílias oriundas das vilas de São Paulo, de Santos e de São Vicente, num movimento de caráter mais espontâneo do que oficial, deslocaram-se para o sul, dando início aos povoados de Curitiba, no planalto; de São Francisco do Sul e Laguna, na costa litorânea; e Desterro, no centro ocidental da ilha de Santa Catarina. Políticas mais sistemáticas da monarquia portuguesa para a incorporação desses territórios ocorreram somente no século seguinte, em especial após a metade do setecentos, quando a alteração da geopolítica lusitana veria na ocupação contínua do território uma estratégia mais efetiva de conquista.

As povoações surgiram seguindo o fluxo da corrente migratória a partir de São Paulo acompanhando, igualmente, o caminho das tropas de vacuns e muares que se dirigiam para Sorocaba e, daí, para as minas de ouro do centro do Brasil. Nesse movimento, a Coroa operou a elevação ao estatuto de vila de antigos assentamentos bandeirantes que, gradativamente, avançavam para 0 extremo sul. ${ }^{20}$ Sorocaba, antigo arraial paulista, era criada vila em 1661 e tornou-se o principal ponto de comércio dos animais trazidos das extensas planícies e planaltos das "terras disputadas" meridionais. ${ }^{21} \mathrm{~A}$ iniciativa paulista de ampliar terras, procurar metais preciosos e escravizar indígenas foi, em grande medida, responsável pela ampliação do território por súditos portugueses. De tal forma, a sociedade que se criava reproduzia essas práticas, mantendo por longo tempo ligações com as principais famílias paulistas. ${ }^{22}$ As Câmaras do sul não raro foram ocupadas por ramos de famílias bandeirantes que atribuíam a si tal privilégio mediante seus méritos de conquistadores, quando não eram completamente dominadas por esses.

Na primeira fase da expansão, destaca-se a presença reduzida da Coroa, visto que as capitanias de São Vicente e de Paranaguá ainda pertenciam a donatários, passando à monarquia somente com a criação da capitania de São Paulo e Minas do Ouro, em 1709. Nesse sentido, a criação da vila litorânea de Paranaguá (1646) e da sertanista Curitiba deveram muito pouco ao poder régio propriamente dito, marcando-se como iniciativa de poderes privados. $\mathrm{A}$ criação de vilas a partir do povoamento prévio e da expansão vicentina e paulista (para diferentes regiões) desmente a ideia de que a criação dos

\footnotetext{
${ }^{20}$ Destaque-se diferença entre "povoar" e "criar vila", uma vez que a primeira expressão se refere ao assentamento humano, enquanto que a segunda contempla a mudança de estatuto jurídico com a implantação de uma Câmara e a delimitação de sua jurisdição.

${ }^{21}$ A denominação "terras disputadas" se origina da expressão de Dauril Alden "Debatable Lands", cuja delimitação é simultaneamente espacial e histórica, uma vez que fruto da disputa entre as monarquias ibéricas. ALDEN, Dauril, op.cit., p. 59.

22 HAMEISTER, Martha Daisson. O Continente do Rio Grande de São Pedro: os homens, suas redes de relações e suas mercadorias semoventes (c. 1727-c. 1763). Rio de Janeiro: Dissertação de Mestrado, PPGHIS-UFRJ, 2002.
} 
municípios no Brasil precedeu ao povoamento do território, o que resultaria na modelagem da atividade econômica e do estabelecimento social pelo ordenamento jurídico. ${ }^{23}$

\begin{tabular}{|c|}
\hline $\begin{array}{l}\text { Vilas portuguesas no extremo sul da América - } \\
\text { datas de criação }\end{array}$ \\
\hline 1646 - Paranaguá. \\
\hline 1660 - São Francisco do Sul \\
\hline 1661 - Sorocaba. \\
\hline 1693 - Curitiba. \\
\hline 1714 - Laguna. \\
\hline 1726 - Desterro. \\
\hline 1747 - Rio Grande de São Pedro. \\
\hline 1766 - Lages. \\
\hline 1770 - Itapetininga. \\
\hline 1771 - Guaratuba. \\
\hline 1797 - Antonina. \\
\hline 1798 - Castro. \\
\hline 1806 -Vila Nova do Príncipe. \\
\hline
\end{tabular}

A povoação de São José dos Pinhais de Curitiba era um paradouro importante para os tropeiros que do sul se dirigiam à Sorocaba, motivo pelo qual abrigava um registro de gado para cobrança de impostos. ${ }^{24} \mathrm{O}$ fluxo constante de tropas pontuaria o caminho de Curitiba à Sorocaba de diversos arraiais que, eventualmente, se tornariam novas vilas, como Itapetininga (1770). A proximidade com o modelo paulista de sociedade refletiu-se não apenas pela ligação comercial, visto que em seus primeiros anos o controle da vila era marcado pela chefia personalista de um chefe local, o capitão povoador Matheus Martins Leme. $O$ poder pessoal de Leme provinha, em grande medida, de seu posto, nomeado que fora por Gabriel de Lara, simultaneamente ouvidor da vila de Paranaguá e procurador do Marquês de Cascais, donatário da capitania de Paranaguá. A despeito do pedido dos chefes de família locais para criação de vila e do efetivo levantamento de pelourinho, em 1668, não foram realizadas eleições para os cargos municipais até o ano de 1693, de modo que a autoridade local coube ao capitão povoador até sua velhice, quando se

\footnotetext{
${ }^{23}$ Tal a visão formulada por Raimundo Faoro na década de 1950 e, por vezes, sustentada em trabalhos recentes. FAORO, Raimundo. Os Donos do Poder. Formação do patronato político brasileiro. São Paulo: Globo, 2001, p. 171. SANTOS, Rosângela Maria Ferreira dos. E mandem convocar o povo... - eleições municipais em Curitiba (1735-1765). In Anais de V.a Jornada Setecentista. Curitiba: 2003, p. 10.

${ }^{24}$ HAMEISTER, Martha Daisson. Op. Cit. Cap. 3 \& HAMEISTER, Martha Daisson. As informações do Registro de Curitiba, a passagem das tropas vindas do sul e a importância dos gados (1751, 1769, 1770 e 1771). In: BOTELHO, Tarcísio Rodrigues. [Et. Al.]. História quantitativa e serial no Brasil: um balanço. Goiânia: ANPUH-MG, 2001.
} 
elegeram os primeiros representantes dentre os homens bons e regularizou-se a condição da vila. ${ }^{25}$

O início do processo eleitoral em Curitiba não significou o fim da influência das famílias paulistas na vila. A estirpe do capitão Martins Leme que após o falecimento de Gabriel de Lara acumulou a posição de procurador do Marquês de Cascais - manteve projeção na Câmara. Somados filhos, genros e netos, o capitão teve 11 descendentes exercendo ofícios no conselho entre 1693 e 1723. Juntamente ao clã de conquistadores de Balthazar Carrasco dos Reis, com o qual se interligavam por inúmeros matrimônios, eles constituíam $37 \%$ dos 59 homens que ocuparam cargos nos trinta primeiros anos da vila. Esse número expressivo deveu-se menos aos descendentes diretos do que aos que se agregaram às duas estirpes através do casamento com suas filhas e netas. O elo de perpetuação na instituição camarária dava-se pela ligação entre sogro e genro mais do que pela sucessão patrilinear, elemento que incide no alargamento das redes sociais e de poder dos potentados curitibanos. Os bons casamentos para as filhas selecionavam pretendentes oriundos de outras famílias paulistas e proprietários de sesmarias mantendo o status adequado na comunidade: a concentração fundiária em poucas mãos e o acesso restrito aos ofícios da república. ${ }^{26}$

As famílias Leme e Carrasco dos Reis demonstraram presença frequente na Câmara por seu número ampliado e igualmente pela reiterada ocupação de ofícios. Guilherme Dias Cortes, casado com uma das filhas de Balthazar Carrasco dos Reis, chegou a ser eleito nove vezes para o conselho. Gaspar, filho de Balthazar, ocupou 12 ofícios entre 1696 e 1720, ou seja, esteve presente em $80 \%$ das 15 Câmaras do intervalo. Gaspar casou-se com uma neta do antigo capitão povoador Matheus Martins Leme e filha de Antônio Costa Velloso, que também foi oficial em 6 ocasiões. 0 entrecruzamento das duas famílias fez com que o conselho se mantivesse como um baluarte dessas estirpes de ascendência paulista/vicentina, de modo a reiterar seu estatuto de "principais da terra" e sua projeção política. ${ }^{27}$

As vilas litorâneas de Laguna e Desterro eram igualmente representantes do modelo bandeirante de povoamento, no entanto em latitudes mais meridionais. Laguna, a mais antiga, permaneceu por muito tempo como a povoação/vila mais ao sul do Brasil e dela partiam soldados e alimentos para a Colônia do Sacramento, integrando esses espaços. Serviu ainda de ponto de partida para expedições exploratórias e de povoamento que terminaram por ocupar, em definitivo, a região dos Campos de Viamão, originando a capitania do Rio Grande de São Pedro. Já Desterro fora fundada por Francisco Dias Velho,

\footnotetext{
${ }^{25}$ A fundação de Curitiba deu-se em três etapas distintas: a primeira, em 1650, com a ereção de uma capela; a segunda, em 1668, com a tomada de posse em nome do donatário da capitania e construção do pelourinho; e, a última, com a criação da Câmara e eleição de seus oficiais. PEREIRA, Magnus Roberto de Mello; SANTOS, Antônio Cesar de Almeida. O Poder Local e a Cidade. A Câmara Municipal de Curitiba (séculos XVII a XX). Curitiba: Aos Quatro Ventos, 2000, p. 22-24.

${ }^{26}$ JORGE, Valesca Xavier Moura. Família e Poder: um estudo sobre a sociabilidade na Curitiba setecentista. In. Anais da V.a Jornada Setecentista. Curitiba: 2003, p. 11.

${ }^{27}$ Idem.
} 
por volta de 1675, enquanto Laguna devia sua existência aos esforços de Domingos de Brito Peixoto; ambos pertenciam à antigas famílias vicentinas. ${ }^{28}$ Essa ligação significa que reproduziam a ocupação espacial praticada por seus antecessores, baseada na contínua apropriação de terra, na exploração de mão de obra indígena e na perseguição das riquezas minerais. Essas últimas, se não pudessem ser localizadas em jazidas, que se supunham existir na região, esperava-se que seriam obtidas por meio de comércio com os espanhóis de Buenos Aires. Por fim, a exploração de uma nova riqueza se delinearia: a caça de gado selvagem para retirada de couros, atividade que foi decisiva no estabelecimento populacional e posterior ampliação do território. ${ }^{29}$

A atuação da Câmara de Laguna, na primeira metade do século XVIII, esteve fortemente ligada à família do fundador da povoação, Domingos de Brito Peixoto, em especial por parte de seu filho Francisco o qual se manteve como capitão-mor da vila por cerca de 15 anos. Enquanto Domingos, natural de São Vicente, retornou logo à sua residência na vila de Santos, Francisco fez da povoação seu protetorado. O legado de seus antepassados bandeirantes redundou em controle personalista pouco preocupado em seguir as recomendações metropolitanas e que muitas vezes sujeitava a atuação camarária aos interesses e caprichos da autoridade maior da vila: o capitão-mor filho do fundador da localidade. Diante da legitimidade garantida pela antiguidade, da autoridade do posto militar e da ampliada parentela de Francisco (que incluía aliados de nações indígenas), a Câmara lagunense viu-se em segundo plano como porta-voz política da comunidade. ${ }^{30}$ Contudo, circulavam no conselho partidos divergentes, formados por redes de aliados próprias que incluíam desde outras famílias paulistas até marinheiros franceses que aportavam clandestinamente na ilha de Santa Catarina para comerciar com a população, fato que concedia aos embates uma importância mais ampla que a da esfera local. Das divergências entre facções - tributárias de rixas vicentinas e paulistas - resultou a decisão régia de criar a vila na ilha em questão, separando a disputa entre potentados locais através do recorte jurisdicional. $^{31}$ As vilas catarinenses, na primeira metade do século XVIII, dependiam em grande medida das alianças com as antigas famílias de São

\footnotetext{
${ }^{28}$ O Visconde de São Leopoldo, ele mesmo natural da vila de Santos e descendente de famílias paulistas, relatou no século XIX a fundação de Desterro como uma empresa familiar tipicamente bandeirante: "Afirmam que pelos anos de 1651, Francisco Dias Velho Monteiro partira do porto de Santos, levando dois filhos, duas filhas, quinhentos índios domesticados e um homem branco de nome José Tinoco, com sua mulher, um filho e duas filhas e com eles principiara a povoar a deserta Ilha dos Patos". PINHEIRO, José Feliciano Fernandes (Visconde de São Leopoldo). Anais da Província de São Pedro. Porto Alegre: Mercado Aberto, 1982, p. 216.

${ }^{29}$ OSÓRIO, Helen, op.cit.,.; HAMEISTER, Martha Daisson. O Continente do Rio Grande de São Pedro..., op.cit.

${ }^{30}$ KÜHN, Fábio. Gente da Fronteira: família, sociedade e poder no sul da América Portuguesa século XVIII. Niterói: Tese de Doutorado, PPG em História da Universidade Federal Fluminense, 2006, p. 39-58.

31 Os detalhes da disputa e uma análise de suas ramificações paulistas, bem como a interpretação da criação da vila de Desterro, podem ser vistos em KÜHN, Fábio. Op. Cit. p. 4150.
} 
Paulo, demonstrando a manutenção de suas alianças e a necessidade que o império lusitano tinha de contar com seus vassalos para a expansão de seus domínios, em particular porque esses adentravam terras oficialmente espanholas (segundo o ainda vigente Tratado de Tordesilhas de 1494).

Após a criação da vila de Desterro na ilha de Santa Catarina, o ânimo da Coroa em criar novas vilas na região meridional arrefeceu, seguindo-se um intervalo prolongado no processo. Ocorre que as pretensões de Lisboa se alteravam nesse momento propiciando o surgimento dos primeiros governos encabeçados por agentes diretamente nomeados pelo monarca português. A fundação do forte de Jesus Maria José (1737), na chamada barra do Rio Grande (atual lagoa dos Patos), é o ponto de inflexão da política platina portuguesa. Ao mesmo tempo em que a fortificação tinha por objetivo prestar socorro à isolada Colônia do Sacramento, ela fomentava a criação de nova povoação que com as estâncias de gado de Viamão e as vilas de Desterro e Laguna eliminavam hiatos espaciais. A efetiva ocupação da região do canal do Rio Grande deu-se na conjuntura de guerra entre portugueses e espanhóis que, na região do Prata, se concentrava na Colônia do Sacramento. Uma expedição enviada pela Coroa, destinada originalmente a desembarcar na região de Montevidéu, acabou ocupando as duas margens da barra do Rio Grande no início de 1737, sob o comando do brigadeiro José da Silva Pais o qual seria o primeiro comandante do novo território lusitano. ${ }^{32}$ Por ser uma região em disputa, Portugal utilizou uma forma híbrida de colonização em Rio Grande: ao mesmo tempo que era uma fortaleza militar, era também uma colônia de povoamento. Após alguns meses no comando, Silva Pais entregou o presídio a André Ribeiro Coutinho, cujo governo foi marcado pela tentativa de consolidação do domínio lusitano na região. Ele chegou ao Rio Grande de São Pedro em 1737, com a patente de coronel, acompanhando Silva Pais. Após ter deixado o governo, no final de 1740 , chegou a comandante da guarnição militar do Rio de Janeiro. ${ }^{33}$

Em 11 de agosto de 1738, uma Carta Régia ordenava que se criasse um governo na ilha de Santa Catarina separado da capitania de São Paulo e subordinado diretamente ao Rio de Janeiro, cidade de onde deviam "sair todos aqueles socorros, e ordens" que fossem precisos para a defesa de Sacramento e ajuda do novo estabelecimento do Rio Grande. ${ }^{34}$ Tais medidas no reinado de D. João $\mathrm{V}$ tinham por objetivo consolidar, frente às ameaças estrangeiras, a soberania portuguesa nesse extenso espaço que se abria entre a capitania de São Paulo e o Rio da Prata - grande parte ainda incógnito -, onde estavam em

\footnotetext{
${ }^{32}$ Para um estudo sobre seus governos no Rio Grande e Santa Catarina, ver PIAZZA, Walter F. O Brigadeiro José da Silva Paes: estruturador do Brasil Meridional. Florianópolis: Ed. da UFSC / FCC Edições; Rio Grande: Ed. da FURG, 1988.

33 BARRETO, Abeillard. Bibliografia Sul-riograndense. Volume I, p. 380-381; BOXER, Charles R. A Idade de Ouro do Brasil. Rio de Janeiro: Nova Fronteira, 2000, p. 260-261 e 327. Ribeiro Coutinho nos legou uma saborosa descrição do Rio Grande nos primeiros tempos, além de ser autor de uma "Memória" (1740), na qual deixou importantes instruções para o seu sucessor acerca do modo de governar o Rio Grande de São Pedro. AHU-RJ (Castro Almeida), nº 16839. "Memória dos serviços prestados pelo Mestre de Campo André Ribeiro Coutinho no Governo do Rio Grande de São Pedro", dirigida a Gomes Freire de Andrade.

${ }^{34}$ Revista do IHGRGS, n. 109 a 112, Ano 1948, p. 132 e 133. Provisão régia de 11.08 .1738 dirigida a Gomes Freire de Andrade, governador e capitão-general do Rio de Janeiro.
} 
jogo o comércio da prata peruana, as minas descobertas e a descobrir no sertão, o gado solto pelos campos, as madeiras, e tantos outros recursos que aquelas terras e mares poderiam fornecer ou produzir ao comércio europeu. ${ }^{35}$ Além disso, as mudanças inseriam-se no esforço mais sistemático de reestruturação administrativa da monarquia com vistas à ampliação da autoridade régia sobre determinados espaços estratégicos do Império Português. ${ }^{36}$ Reduzia-se o poder jurisdicional da capitania de São Paulo e submetiam-se aquelas pequenas vilas do sul, com seus poderes locais instituídos ao controle de comandantes militares, diretamente subordinados ao governador e capitão general do Rio de Janeiro, e, após 1763, ao vice-rei do Estado do Brasil. O controle que essas autoridades, sobretudo os vice-reis, exerceram sobre os governadores subalternos do sul foi não só oficial, mas efetivo, de maneira, portanto, distinta da subordinação existente entre os governadores das capitanias gerais com os vice-reis, que ficava mais no plano formal. ${ }^{37}$

Situada a meio caminho entre o Rio de Janeiro e o Rio da Prata, a Itha de Santa Catarina constituiu-se desde o século XVI como porto privilegiado ou, pelo menos, como importante ponto de referência náutica aos navegadores europeus nos mares do sul, como nos mostram os relatos de viagens e a extensa cartografia produzida sobre 0 Novo Mundo na Época Moderna. ${ }^{38}$ Fazendo a rota do Atlântico-Pacífico, pelo Cabo Horn, ou do Atlântico-Alto Peru, via rio da Prata, muitos navegadores aportavam nela para reabastecerem-se de alimentos frescos e de água, curarem os enfermos e restaurarem suas embarcações. A importância regional e jurisdicional da ilha viu-se realçada, em 1748 , quando passou a sediar a comarca da ouvidoria cujo magistrado atuava também sobre o Rio Grande.

Enquanto isso, o governo de Diogo Osório Cardoso (1741-1752) na comandância do Rio Grande mostrava-se bastante atribulado. 0 episódio mais conhecido da sua administração refere-se à revolta do Regimento dos Dragões

\footnotetext{
${ }^{35}$ Ver, entre outros, BICALHO, Maria Fernanda. A Cidade e o Império. O Rio de Janeiro no século XVIII. Rio de Janeiro: Civilização Brasileira, 2003; e, da mesma autora, A Cidade do Rio de Janeiro e a Articulação da Região em torno do Atlântico-Sul: Séculos XVII e XVIII. Revista de História Regional, vol. 3, n. 2, inverno (1998). Disponível em: http://www.rhr.uepg.br/v3n2/fernanda.htm. Acesso em: 04 mar. 2006.

${ }^{36}$ Ver, entre outros, COUTO, Jorge. D. João V. In MEDINA, João. (Dir.) História de Portugal dos tempos pré-históricos aos nossos dias. Vol. VII - Portugal Absolutista. Alfragide: Ediclube, s/d., p. 244; e CARDIM, Pedro. O Processo Político (1621-1807). In MATTOSO, José. (Dir.) História de Portugal. O Antigo Regime. Vol. 4. Lisboa: Estampa, 1997.

37 SILVA, Augusto da. A Ilha de Santa Catarina e sua Terra Firme: estudo sobre o governo de uma capitania subalterna (1738-1807). São Paulo: Tese de Doutorado: PPG/História Econômica, Universidade de São Paulo, 2008, pp. 151-161.

38 Uma relação bem completa dos viajantes europeus que passaram pela Ilha de Santa Catarina, no século XVI, com biografia dos navegadores e objetivos das viagens, encontra-se em MELLO, Amilcar d'Ávila. Crônicas das Origens: Santa Catarina na era dos descobrimentos geográficos. Florianópolis: Expressão, 2005. Para as representações da Ilha no século XVII ver, entre outros, o livro MAPA: Imagens da Formação Territorial Brasileira, organizado por ADONIAS, Isa.; FURRER, Bruno. et al. Rio de Janeiro: Fundação Emilio Odebrecht, 1993; Para os séculos XVIII e XIX, HARO. A. Palma de (Org.). Ilha de Santa Catarina: Relatos de viajantes estrangeiros nos séculos XVIII e XIX. 3a. Ed. Revista. Florianópolis: EdUFSC; Lunardelli, 1990.
} 
(1742), ocorrida em um momento de grande dificuldade para a manutenção do presídio, assoberbado com a falta de embarcações que trouxessem os alimentos necessários para a subsistência da guarnição e população civil. ${ }^{39}$ Somente em fins de 1751 a povoação do Rio Grande seria elevada formalmente à categoria de Vila, com a instalação de uma Câmara e a institucionalização do domínio político lusitano. Durante toda a primeira metade do século XVIII, o território do atual Rio Grande do Sul não conheceu a presença da instituição típica da representação do poder local no Império português. Desde a criação da vila de Laguna, em 1714, todo o território meridional estava sujeito às "justiças" emanadas do conselho. Teoricamente, os moradores de Rio Grande também deviam estar submetidos à jurisdição da Câmara lagunense. Todavia, os conflitos entre os governadores militares do Rio Grande e os oficiais de Laguna foram bastante comuns, o que nos sugere que a criação de uma Câmara em Rio Grande tenha sido uma decorrência desses conflitos jurisdicionais.

Alguns meses depois da instalação da vila, Osório era substituído na comandância pelo tenente-coronel Pascoal de Azevedo (1752-1760). ${ }^{40}$ Inaugurava-se nova conjuntura, marcada pela vinda de Gomes Freire ao Sul e ao início das tentativas de demarcação do Tratado de Madri. Se, na primeira metade do século XVIII, o território sulino foi incorporado de maneira inequívoca ao Império português, na segunda metade ocorreria a consolidação dessa ocupação, marcada pela elevação da importância da capitania do Rio Grande de São Pedro e pelo abandono temporário das pretensões platinas. Inclusive o ano de 1760 abrigou a promoção do Rio Grande de São Pedro de comandância militar à capitania subalterna ao Rio de Janeiro, mas agora desligada de Santa Catarina. A criação desse governo separado deu-se em função da necessidade de maior flexibilidade para a administração local, diante da possibilidade de recrudescimento das hostilidades na fronteira. ${ }^{41}$ Para 0 cargo foi nomeado o coronel Inácio Elói Madureira (1760-1763), que fora governador da praça de Santos e era homem tido como capaz pelo Conde de Bobadela. Porém, as expectativas de Gomes Freire se frustraram e Madureira acabou acusado de desobediência, chegando a ter os bens sequestrados pela Coroa devido à perda da praça do Rio Grande. ${ }^{42}$ Assim como seus colegas da Colônia que caíram em desgraça no governo metropolitano, ele foi responsabilizado, com outros oficiais militares do Rio Grande, pela capitulação

\footnotetext{
39 QUEIROZ, Maria Luiza Bertulini. A Vila do Rio Grande de São Pedro, 1737-1822. Rio Grande: Editora da FURG, 1987, p. 72-73. Conforme o relato dos náufragos ingleses Buckeley e Cummins, que estavam em Rio Grande naquela altura, "faz vários dias que o povo está agitado, porque o navio não chega, apesar do vento estar estado favorável há mais de três semanas; a escassez de mantimentos torna-o receoso do futuro". Citado em Queiroz, op. cit.

40 MIRANDA, Márcia Eckert. Continente de São Pedro: administração pública no período colonial. Porto Alegre: CORAG, 2000, p. 55; Documentos Históricos, vol. 94, Rio de Janeiro: Biblioteca Nacional, 1951 , p. 130-131.

${ }^{41}$ CESAR, Guilhermino. História do Rio Grande do Sul. Porto Alegre: Globo, 1970, p.165.

42 AHU-RS. Cx.2, doc. 78, Decreto de nomeação, 19.08.1760; AHU-RJ, no 5835, Ofício de Bobadela ao Conde de Oeiras, 21.02.1761; AHU-RJ, no 7594, Auto de sequestro, 23.03.1764.
} 
da vila para as forças espanholas em abril de $1763 .{ }^{43}$ Madureira não sobreviveu muito após a trágica derrocada, pois faleceu na ilha de Santa Catarina no início do ano seguinte, deixando o Continente em estado de convulsão.

Com efeito, a tomada da vila do Rio Grande pelos espanhóis provocou uma grande alteração, pois além das autoridades portuguesas (governador, provedor da Fazenda e oficiais camarários), a maior parte da população da praça fugiu em direção ao arraial de Viamão, em um movimento de êxodo que teve enormes impactos para a própria governabilidade da capitania. Cabe lembrar que a vila de Rio Grande, além de praça forte, era o único porto marítimo da capitania, o que impôs uma dificuldade logística adicional para a defesa do disputado território. Todo o abastecimento e desembarque de tropas teria que ser feito na ilha de Santa Catarina ou na vila de Laguna, com o restante do trajeto até o Continente sendo feito via terrestre, por largas distâncias.

Durante a década em que o arraial de Viamão foi sede do poder político e administrativo do Continente, o cargo de governador foi exercido por três diferentes militares. O tenente-coronel José Custódio Sá e Faria (1764-1769) era engenheiro militar, além de ser um cartógrafo renomado o qual conhecia a região desde a década de 1750, quando fora um dos demarcadores portugueses. $^{44}$ Observadores contemporâneos apontavam supostas irregularidades cometidas pelo governador sendo que, nesse ponto, a acusação parece ter procedência. ${ }^{45}$ Governando em um período de crise no Continente, duramente atingido pela situação bélica, José Custódio não pôde (ou não quis) executar as determinações do seu Regimento que lhe ordenavam agir particularmente em quatro áreas: o estabelecimento dos colonos açorianos, 0 controle sobre os índios, o fomento da agricultura e o estabelecimento de uma povoação estratégica. Desses objetivos, cumpriu na íntegra apenas o último, com a criação da freguesia de Taquari, onde instalou alguns casais dos Açores. Não pôde instalar todos os ilhéus, supostamente por temer entrar em confronto com a elite local, especialmente os grandes proprietários de terras que, na sua maioria, também eram militares. ${ }^{46}$ De fato, o mais apropriado seria pensar que o governador estivesse efetivamente de acordo com vários desses grandes proprietários os quais não tinham o menor interesse em dividir as terras disponíveis.

O coronel José Marcelino de Figueiredo sucedeu a José Custódio, governando o Continente por mais de uma década, entre abril de 1769 e o

\footnotetext{
${ }^{43}$ Devassa sobre a entrega da Vila do Rio Grande às tropas castelhanas (1764). Rio Grande: Bibliotheca Rio-grandense, 1937.

${ }^{44}$ BARRETO, Abeillard. Bibliografia Sul-Riograndense. v. I, Rio de Janeiro: Conselho Federal de Cultura, 1973, p. 486-491.

${ }^{45}$ ANRJ. Fundo Marquês do Lavradio, Microfilme 024-97, Notação 16.78 a 16.79: Carta do sargento-mor Francisco José da Rocha para o Vice-rei Marquês do Lavradio. Viamão, 27.01.1772. Se as denúncias de Rocha forem fidedignas, o governador José Custódio de Sá e Faria teria aderido mesmo aos interesses da elite local. Somente dessa forma se consegue entender sua associação ao "bando" encabeçado por Rafael Pinto Bandeira, que estava envolvido com o contrabando de gado dos domínios espanhóis.

${ }^{46}$ OSÓRIO, Helen, op.cit., p. 105-111.
} 
início de 1780. Nesse período, o único interregno é aquele que corresponde ao governo interino do tenente-coronel Antônio da Veiga Andrade (entre outubro de 1771 e junho de 1773), quando José Marcelino foi chamado ao Rio de Janeiro para dar explicações ao vice-rei ${ }^{47}$ Logo nos primeiros meses após seu retorno ao Rio Grande (janeiro de 1774), ele havia de enfrentar um enorme desafio, representado pela nova tentativa de invasão do Rio Grande pelos castelhanos. Teve uma atuação destacada na defesa da fronteira do Rio Pardo, o que lhe valeu bastante prestígio perante a Coroa, pois recebeu promoção por carta régia de 14 de junho de 1774; a patente de Brigadeiro de Cavalaria.48

No entanto, a conjuntura de guerra impedia que se prescindisse dos préstimos militares da elite local, especialmente do líder local Rafael Pinto Bandeira. Em uma carta em que acusava esse de contrabandista, José Marcelino repetiu uma máxima, muito utilizada pelos administradores coloniais. Como a situação estava incerta para o sucesso das armas portuguesas, ele confessava que tinha que fechar os olhos a certas irregularidades, pois "me achei na necessidade de fazer dos ladrões fiéis". ${ }^{49}$ No entanto, pacificada a capitania, José Marcelino reabriu as investigações acerca do potentado, determinando a prisão de Rafael Pinto Bandeira em 1779. Diante da inconcludência das provas, o caso foi remetido ao Rio de Janeiro onde resultou em um Conselho de Guerra que acabaria, senão inocentando completamente, pelo menos aliviando o coronel Pinto Bandeira das acusações que the eram imputadas. Em 08 de janeiro de 1780, um ofício da Corte mandou restituir Rafael Pinto Bandeira ao seu posto, determinando a saída do agora brigadeiro José Marcelino do governo do Continente do Rio Grande.

O sucessor foi o brigadeiro Sebastião Xavier da Veiga Cabral da Câmara, que governou por mais de duas décadas (1780-1801), apesar de longos períodos de interinidade. $O$ novo governador inicialmente manteve-se em Porto Alegre (para onde a sede do governo transferiu-se em 1773) ou no porto de Rio Grande, procurando tomar pé da situação do Continente depois de mais de dez anos de guerra. No entanto, em função da sua nomeação, em 1781, como comissário-chefe português da demarcação do Tratado de Santo Ildefonso, ele manteve-se afastado das funções administrativas diretas, por se achar a maior parte do tempo na fronteira, o que levou aos governos interinos de Rafael Pinto Bandeira (1784-1786 e 1790-1793) e Joaquim José Ribeiro da Costa (1786-1790). Quanto ao primeiro governador interino, seu perfil já foi delineado, ele que foi o único representante da elite local a chegar ao topo da hierarquia regional. A rede de contrabando e poder de Rafael Pinto tem sido analisada como exemplo bem acabado de estruturação de um "bando" bastante articulado, que seria dominante na política da capitania durante o último quartel

\footnotetext{
47 José Marcelino de Figueiredo era natural de Bragança, sendo seu verdadeiro nome Manuel Jorge de Sepúlveda. A troca deveu-se ao fato de que o dito Sepúlveda assassinara um oficial britânico, vindo foragido para o Brasil em 1765. A esse respeito, ver BARRETO, op. cit., p. 519520 e ALDEN, Dauril, op.cit., p. 449-452.

${ }^{48}$ ALDEN. op. cit. p. 125-132.

49 BNL. Divisão de Reservados. Códice 10854, carta de José Marcelino de Figueiredo ao Marquês do Lavradio: Porto Alegre, 09 de maio de 1775.
} 
do século XVIII. ${ }^{50}$ Ribeiro da Costa, por seu turno, havia acompanhado o general João Henrique de Böhm no tempo da guerra contra os espanhóis e, segundo o vice-rei Vasconcelos, era "um oficial muito zeloso do serviço, desinteressado, e pronto na execução das ordens que se the encarregam". A primeira tarefa que Ihe foi ordenada pelo vice-rei seria "com todo o disfarce e segredo possível adquirir as notícias mais exatas sobre os referidos contrabandos, e os principais cabeças que os tem promovido e continuado com tão estranha e desordenada laxidão". ${ }^{51} \mathrm{Em} \mathrm{1801,} \mathrm{no} \mathrm{final} \mathrm{do} \mathrm{governo} \mathrm{de} \mathrm{Cabral}$ da Câmara, um pouco antes do seu falecimento, aconteceria a tomada dos Sete Povos das Missões, por meio da ação de um grupo de aventureiros e desertores do Exército, possivelmente associados aos líderes indígenas (os caciques guarani) e acobertados pelo comandante militar da fortaleza de Rio Pardo. Tal feito, além de incorporar à capitania alguns milhares de novos súditos, praticamente dobrava a extensão do seu território. ${ }^{52}$

Por fim, com a morte do longevo governador, assumiria interinamente 0 cargo o brigadeiro Francisco João Roscio, militar de larga experiência e conhecimento da capitania. ${ }^{53}$ Ele ficaria por mais de um ano no cargo, enquanto aguardava a chegada do novo governador, o chefe de esquadra Paulo José da Silva Gama (1803-1809), o último subalterno ao Rio de Janeiro. O governo de Gama foi marcado pela dinamização econômica e pela tentativa de reorganização administrativa do Continente. Com efeito, uma das principais preocupações desse administrador seria a aplicação da justiça na capitania, que ainda então sofria nesse aspecto devido à precariedade da estrutura institucional, pois inexistiam em seu território juízes de fora ou ouvidores residentes. Ainda em 1803, solicitava ao Príncipe Regente que fossem criadas quatro novas vilas no Rio Grande de São Pedro, demanda que seria atendida somente a partir de 1809. No plano econômico, sua principal realização seria a implementação de uma Alfândega em Porto Alegre, para melhor poder arrecadar as imposições fiscais naquela conjuntura de crescimento econômico. ${ }^{54}$

\footnotetext{
${ }^{50} \mathrm{GIL}$, Tiago L. Infiéis transgressores. Elites e contrabandistas nas fronteiras do Rio Grande e do Rio Pardo (1760-1810). Rio de Janeiro: Arquivo Nacional, 2007, p. 127-167.

${ }^{51}$ SILVA, Augusto da. Rafael Pinto Bandeira: de bandoleiro a Governador. Relações entre os poderes privado e público em Rio Grande de São Pedro. Porto Alegre: Dissertação de Mestrado, PPG-História/UFRGS, 1999, p. 134.

${ }^{52}$ As exceções a essa regra podem ser encontradas na obra de CAMARGO, Fernando da Silva. O Malón de 1801: a Guerra das Laranjas e suas implicações na América meridional. Passo Fundo: Clio, 2002; e em GARCIA, Elisa F. As diversas formas de ser índio: políticas indígenas e políticas indigenistas no extremo sul da América portuguesa. Tese de Doutorado em História. Niterói: PPG-História/UFF, 2007.

53 Antes de assumir interinamente o governo da capitania, fora também governador de Moçambique (1797-1801).

${ }^{54}$ Para uma descrição da situação geral do Rio Grande às vésperas da chegada da Corte, ver MAGALHÃES, Manuel Antônio de. Almanack da Vila de Porto Alegre, com reflexões sobre o estado da capitania ${ }^{54}$ do Rio Grande do Sul. RIHGB, tomo XXX, $1^{\text {a }}$ parte, vol. 34 (1867).
} 


\section{Os governadores das franjas: uma caracterização geral}

Os ocupantes dos governos da Colônia do Sacramento, da Ilha de Santa Catarina e do Rio Grande de São Pedro demonstram possuir características semelhantes, em particular no caso dos dois últimos. Contudo, algumas diferenças também devem ser arroladas, a começar pelo número de governadores, pois embora a existência da Colônia tenha se prolongado por cerca de um século (1680-1777), a quantidade de governadores efetivos foi inferior ao da capitania do Rio Grande (1737-1807) e à de Santa Catarina (1738-1808), considerando que no caso destas o período abrangido é significativamente menor, comportando somente sete décadas.

Foram identificados dez governadores na Colônia do Sacramento no período compreendido entre 1680 e 1777, número idêntico àquele encontrado pelo projeto Optima Pars. Todavia, a relação de governadores com a qual trabalhamos inclui Manuel Lobo, que foi governador do Rio de Janeiro e fundador daquela praça, mas não arrola o brigadeiro Francisco Antônio Cardoso de Meneses e Sousa, que foi efetivamente nomeado para o cargo em 1767, mas não assumiu devido a problemas de saúde. ${ }^{55}$ Os governadores do Rio Grande do Sul totalizam catorze sujeitos, sendo aqui considerados também os ocupantes interinos dos cargos (Francisco Barreto Pereira Pinto, Rafael Pinto Bandeira, Joaquim José Ribeiro da Costa e Francisco João Roscio), na medida em que seus governos somados perfazem mais de uma década, um percentual significativo do marco cronológico investigado. O mesmo critério foi aplicado ao caso catarinense no qual quinze militares ocuparam o cargo de governador da Ilha de Santa Catarina (cinco em caráter interino), além de uma junta governativa no ano de $1800 .^{56}$

A duração dos governos na Colônia do Sacramento parece ter sido maior, apesar da inegável distorção causada na média pela longuíssima extensão do exercício de Antônio Pedro de Vasconcelos. Esse caso, contudo, não foi exceção, pois outros governadores da cidadela também exerceram mandatos por largos períodos, a exemplo de Francisco Naper de Lencastre e Pedro José de Figueiredo Sarmento. No Rio Grande, da mesma forma, temos governos longos, como os de Sebastião Xavier Cabral da Câmara (cerca de duas décadas, com interregnos), Diogo Osório Cardoso e José Marcelino de Figueiredo. Mas, devido aos interinos, a média da duração dos governos na capitania rio-grandense é inferior, pois esses governadores temporários exerciam mandatos de curta duração.

A análise do perfil social desses homens nos conduz à compreensão da valorização e hierarquização dessas conquistas no Império Português, de uma maneira geral, e na América Meridional, em particular. ${ }^{57} \mathrm{Em}$ comparação com os

55 A base eletrônica do Optima Pars inclui ainda a Francisco Ribeiro de Miranda como governador da Colônia. Apesar de nomeado em 1705, ele não chegou a tomar posse, devido à perda da praça. Cf. ALMEIDA, Luís Ferrand de., op.cit., p. 306.

${ }^{56}$ Ver quadros anexos no final do texto.

57 Estudos mais abrangentes sobre essa questão vêm sendo realizados por um conjunto de professores portugueses e brasileiros, entre os quais, destaco: MONTEIRO, N. G.; CUNHA, Mafalda S. da. Governadores e capitães-mores do império atlântico português nos séculos XVII 
militares nomeados para governar as capitanias gerais do Brasil, os governadores subalternos da ilha de Santa Catarina, assim como também os do Rio Grande de S. Pedro e os da Colônia do Sacramento, possuíam status nobiliárquico inferior. Provinham dos estratos mais baixos da nobreza portuguesa ou até de origens mais humildes, configurando sujeitos que alcançaram ao longo de suas carreiras alguma distinção honorífica por meio dos serviços prestados nas conquistas.

Os governadores da Colônia eram quase sempre fidalgos, muito embora se enquadrem na condição de "fidalgo pobre" (caso de Francisco Naper de Lencastre) ou tivessem origens suspeitas, como Sebastião da Veiga Cabral, que tinha ascendência cristã-nova. Os governadores do Rio Grande tinham procedência mais modesta e mesmo origens mecânicas (José da Silva Pais e José Marcelino de Figueiredo) ou representavam as principais famílias da terra, caso do célebre Rafael Pinto Bandeira. Fidalgos efetivos seriam poucos, um deles o brigadeiro Sebastião Xavier da Veiga Cabral da Câmara. A realidade para Santa Catarina aproxima-se dessas, pois três de seus governadores (existe dúvida quanto a um quarto caso) possuíam posição social mais confortável, eram fidalgos já de nascimento, conquanto nenhum pertencente à chamada "primeira nobreza de Corte". 58

Essa diferenciação de origem estaria representada nas patentes dos nomeados para os cargos, pois na Colônia os governadores exerciam, na maioria das vezes, suas funções enquanto mestres de campo ou brigadeiros. A patente militar que a maioria dos governadores da Ilha de Santa Catarina tinham, ou alcançavam, no momento de suas nomeações, era de coronel de infantaria. Vale lembrar que, para as capitanias gerais, os nomeados eram designados como governadores e capitães generais. Quando ocorria de ficarem no posto com uma patente inferior, suplicavam pela promoção. Assim fizeram os governadores interinos José Pereira Pinto e João Alberto de Miranda

e XVIII. MONTEIRO, N. G.; CARDIM, Pedro; CUNHA, Mafalda Soares da. (Orgs.) Optima Pars. Elites Ibero-Americanas do Antigo Regime. Lisboa: ICS, 2005; CUNHA, Mafalda Soares da. Governo e governantes do Império português do Atlântico (século XVII). In BICALHO, Maria Fernanda; FERLINI, Vera (Orgs.). Modos de Governar. Idéias e Práticas Políticas no Império Português - séculos XVI a XIX. São Paulo: Alameda, 2005; na mesma obra, MONTEIRO, N. G. Governadores e capitães-mores do Império Atlântico português no século XVIII; SOUZA, Laura de Mello e., op.cit.

${ }^{58}$ Alertando para os limites de qualquer classificação esquemática da aristocracia portuguesa, N. G. Monteiro propõe a seguinte estratificação para o final da Época Moderna: "Na base, uma vasta e imprecisa categoria que se estendia desde a 'nobreza simples' aos cavaleiros de hábito, a qual incluía todos os licenciados e bacharéis, os oficiais do exército de primeira linha, milícias e ordenanças, os negociantes de grosso trato, os juízes e vereadores de um número indeterminado de vilas e cidades, enfim, todos os que 'viviam nobremente'". Por serem muitos, encontravam-se desqualificados socialmente, levando-os a uma intensa disputa por graças e mercês, como os hábitos das Ordens Militares (de Cristo, de Avis, e de Santiago). Acima desse, um grupo intermediário formado por alguns milhares de fidalgos. "Por fim, a 'primeira nobreza da Corte', constituída por cerca de centena e meia de senhores, comendadores e detentores de cargos palatinos, no cume da qual se encontrava a meia centena de casas dos Grandes do reino". In MONTEIRO, Nuno Gonçalo. Elites e Poder. Entre o Antigo Regime e o Liberalismo. Lisboa: ICS, 2003, p. 144-45. 
Ribeiro. ${ }^{59}$ No Continente do Rio Grande também era preciso ser militar, porém as patentes mantinham-se no patamar das de Santa Catarina; mais da metade dos comandantes ou governadores eram tenentes-coronéis ou coronéis. Ainda assim mostra-se um ponto comum entre os três governos o fato de todos os mandatários exercerem a carreira militar, conditio sine qua non para almejar tal ocupação.

Simultaneamente à busca por graças e mercês como forma de ascender na hierarquia nobiliárquica, os governadores não deixaram de se preocupar com a progressão na carreira militar. De maneira distinta dos títulos nobiliárquicos, que tendiam a se aviltar quanto mais se aproximava o final do Antigo Regime, a promoção no exército colocava-se como uma ascensão segura, concreta e viável para esses indivíduos, sobretudo nos Regimentos estabelecidos na América. Sabe-se que raros foram os governadores não militares nomeados para as conquistas ultramarinas. ${ }^{60}$ Em se tratando de territórios de disputa, com conflitos militares abertos, como era o caso do sul da América, essa formação tornava-se então pré-requisito fundamental.

Em todo o império, a importância dos governos refletia-se na qualidade dos governantes e no caso dos governadores das franjas meridionais não seria diferente. ${ }^{61}$ Ser governador da Colônia mostrava-se mais prestigioso e os indivíduos que ocupavam esses cargos ostentavam indicadores sociais que os qualificavam acima dos comandantes e governadores do restante da América meridional. Outra evidência nesse sentido nos é dada pelo acesso aos hábitos das ordens militares, já que praticamente todos os governadores da Colônia eram cavaleiros da Ordem de Cristo, situação inversa aos do Rio Grande. Contudo, as distinções aristocráticas não se apresentam sempre com total clareza. A posse de títulos sem a obtenção de tenças respectivas poderia não resultar em melhoria das condições sociais e econômicas dos indivíduos. Talvez por isso, Luís Maurício da Silveira, governador da Ilha de Santa Catarina de 1805 a 1817, queixava-se ao vice-rei de que era "Um homem Fidalgo, [mas] pouco socorrido da fortuna...". ${ }^{62}$ Por outro lado, ocorria que a ausência de títulos não impedia a busca de um estilo de vida orientado por regras de Antigo Regime.

José da Silva Paes, primeiro comandante militar do Rio Grande e primeiro governador de Santa Catarina, nasceu em Lisboa, no ano de 1679, filho de pais abastados, mas não nobres. Em 1705 ele requereu mudança do hábito de Santiago, que lhe chegara às mãos por via de sua mulher, D. Maxima Teresa da Silva (ou de Brito), para o de Cristo, "em consideração aos seus próprios serviços", mas Ihe foi negado, visto que seu avô paterno havia sido

\footnotetext{
${ }^{59}$ AHU-SC, cx. 4, doc. 329. Carta José P. Pinto ao Secretário de Estado Martinho de Mello e Castro, em 20.03.1789. AHU-SC, cx. 5, doc. 373. Carta de João Alberto de Miranda Ribeiro ao Secretário de Estado Luiz Pinto de Souza Coutinho, em 24.05.1796. Esse governador encaminhou pelo menos mais um requerimento com esse propósito ao longo dos seis anos e meio de governo, mas sem obter sucesso. Ver AHU-SC, cx. 5, doc. 359.

${ }^{60}$ MONTEIRO, Nuno Gonçalo. Governadores e capitães-mores..., op. cit., p. 108.

${ }^{61}$ MONTEIRO, Nuno Gonçalo F.; CUNHA, Mafalda Soares da. Governadores e capitães-mores do império atlântico português nos séculos XVII e XVIII , op.cit., p.206 e ss.

${ }^{62}$ ANRJ, Cód. 106, vol. 16, fl. 199. Carta ao Príncipe Regente em 03.07.1806.
} 
"Piloto de Navios da Carreira do Brasil, ou seja, um ofício mecânico e, por este

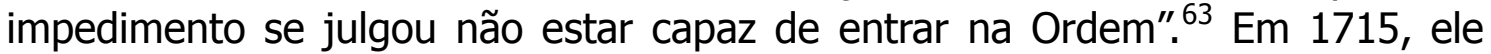
reapresentou a petição, obtendo-a, mas "em sua vida somente", o direito àquela distinção honorífica e mais a tença efetiva de $12 \$ 000$ réis, como remuneração de bons serviços. ${ }^{64}$ Após desempenhar diversos serviços à Monarquia como engenheiro-militar em Açores, no Rio de Janeiro e em suas colônias anexas no sul, projetando e erguendo fortalezas, obras públicas e fundando povoados, ele retornou ao reino na década de 1750, já com idade avançada. Seu domicílio, situado próximo à bica dos Anjos na cidade de Lisboa, era um pequeno palacete, farto em espaço, provido de loja e andar superior, com casa de moços, cocheira, cavalariça e capoeiras, com bons móveis, pratarias e uma biblioteca composta por 437 volumes. Possuía também um escravo, um criado grave e mais três serviçais. "No estilo e na praxe Silva Paes vivia, sem sombra de dúvida, à lei da nobreza". ${ }^{65}$

Contudo, percebe-se que Silva Paes representa a vertente de agentes monárquicos que regressavam ao Reino findo seu tempo de serviço. Nem todos apresentaram esse padrão de conduta e houve aqueles que faleceram durante - cumprimento de suas obrigações. Embora nossos dados sejam ainda lacunares, no Rio Grande nota-se uma fixação maior dos governadores em comparação com a Colônia do Sacramento. Essa fixação foi aferida a partir dos locais em que faleceram, o que a princípio não é garantia de maior vinculação às terras governadas. Todavia, no caso rio-grandense, a maioria morreu em terras americanas, alguns em condição desairosa, como foi a de Inácio Elói Madureira, sepultado na ilha de Santa Catarina e acusado como um dos responsáveis pela perda da vila de Rio Grande em 1763.

Assumir os postos de governo na região das franjas imperiais trazia ainda o risco de mácula na reputação, pois o caso de Madureira não foi o único ou o mais rumoroso. Destaque-se a deserção de José Custódio de Sá e Faria em 1777 para o lado dos espanhóis após sua captura. Na Colônia do Sacramento, em geral, os governadores retornavam ao Reino, apesar de alguns terem falecido in loco, caso de Luís Garcia de Bivar. Também na praça platina exercer o cargo de governador não era isento de riscos, principalmente na fase final da cidadela. Dois governadores desse período terminaram seus dias de forma pouco abonadora, um deles preso no Limoeiro, acusado de ter entregado a praça em 1762 (Vicente da Silva da Fonseca) e o outro degredado para Angola, imputado pela perda definitiva da praça em 1777 (Francisco José da Rocha).

\footnotetext{
${ }^{63}$ PIAZZA, W. O Brigadeiro José da Silva Paes: Estruturador do Brasil Meridional. Rio Grande: EdFURG, 1988, p. 23 e 43.

${ }^{64}$ ARAÚJO, A. C. Livros de uma Vida: Critérios e modalidades de constituição de uma livraria particular no Século XVIII. Revista de História das Idéias. Vol. 20 - O Livro e a Leitura. Coimbra, (1999), p. 153. Das três ordens militares - Avis, Santiago e de Cristo - esta última era a que mais poder e prestígio propiciava ao nobilitado. Ver, sobretudo: OLIVAL, Fernanda. As Ordens Militares e o Estado Moderno: Honra, Mercê e Venalidade em Portugal (1641-1789). Lisboa: Estar, 2001. PIAZZA, W. O Brigadeiro... op. cit, p. 44.

${ }^{65}$ ARAÚJO, A. C. Livros de uma Vida..., op. cit., p. 157.
} 
Possivelmente, em decorrência de conjunturas políticas internacionais ou locais específicas, homens de linhagens mais ilustres foram chamados para exercer o cargo de governador da ilha de Santa Catarina a partir da segunda metade do setecentos. No contexto da Guerra dos Sete Anos (1756-62) - que teve como desdobramentos na região platina a invasão da Colônia do Sacramento e do Rio Grande - fora nomeado governador da ilha, em 1762, Francisco Antônio Cardoso de Meneses e Sousa. Seu pai, Luís Cardoso e Meneses e Sousa, era fidalgo da Casa Real e, sua mãe, Elena Teixeira Castro, provinha também de nobre linhagem. Segundo o viajante francês Pernety, que passou pela Ilha em 1763, Dom Francisco Cardoso era "Coronel, Cavalheiro de Cristo, e de uma ilustre família de Portugal". ${ }^{66}$ A situação periclitante do avanço espanhol requeria homens competentes e a despeito de medidas racionalizantes efetuadas pela Coroa portuguesa, a qualidade dos homens ainda se mesclava em boa medida à qualidade do sangue, ou seja, o legado de serviços de sua família.

A rendição da ilha de Santa Catarina aos espanhóis, em 1777, sem que sua guarnição oferecesse a mínima resistência, soou na América e no reino como uma terrível e humilhante derrota. ${ }^{67} \mathrm{~A}$ invasão evidenciava ainda a vulnerabilidade da praça militar e, por conseguinte, de todas as conquistas portuguesas no sul da América meridional. Passado o susto e restituída ela a Portugal, nos termos do Tratado de Santo Ildefonso, fora designado para recebê-la, em julho de 1778, o coronel Francisco Antonio da Veiga Cabral da Câmara (1777-1779). Era fidalgo da Casa Real, filho primogênito do General da Província de Trás-os-Montes, Francisco Xavier da Veiga Cabral, e neto do Mestre de Campo, General Sebastião da Veiga Cabral. Assim como seu pai e avô, era comendador de três comendas, "todas da ordem de Cristo". ${ }^{68}$ Seu tio, também com o nome de Sebastião da Veiga Cabral, fora governador da Colônia do Sacramento (1699-1705) e seu irmão, Sebastião Xavier da Veiga Cabral da Câmara, governador do Rio Grande (1780-1801). Em 1784, foi nomeado governador e capitão general da Índia, cargo que ocupou até 1807 . No ano seguinte retornou ao Rio de Janeiro junto com a família real, sendo agraciado, em 1810, com o título de visconde de Mirandela. ${ }^{69}$ Para substituí-lo no governo da ilha e dar sequência aos trabalhos de reestruturação daquela colônia portuguesa, fora nomeado outro fidalgo, o coronel de infantaria do Regimento de Bragança Francisco de Barros Morais Araújo Teixeira Homem. Natural de Chaves, em Portugal, era filho do cavaleiro e governador de Lagos, João de

\footnotetext{
${ }^{66}$ PERNETY, A. J. Histoire d'un voyage aux isles Maouines, fait em 1763 \& $1764 \ldots$, in Ilha de $S$. Catarina... op. cit., p. 80 e 81.

${ }^{67}$ Uma das acusações dirigidas contra o Marquês de Pombal, após ser substituído no ministério, era de que "a Praça de Almeida, e a Ilha de Sta. Catarina foram entregues aos castelhanos por ordens particulares" dele. BNL, PBA, 695, mf. 1635. Apologias que tenho escrito sobre cada huma das calumnias, que a ingratidão, e a inveja espalharam contra mim no grande Povo de Lisboa, depois da minha auzencia. Marquês de Pombal, em 2/04/1777. Ver 14a Apologia, fl. 177.

${ }^{68}$ ANTT, Chancelaria de D. Maria I, Lv. 84, fl. 329v.

${ }^{69}$ PIAZZA, W.. Dicionário Político..., op. cit., p. 126.
} 
Barros Pereira do Lago, "gente nobre", e de dona Jerônima Morais, que vivia "de acordo com as leis da nobreza". 70

Um atributo bastante valorizado, ao menos no caso dos governadores do Rio Grande, era a prévia experiência em expedições de reconhecimento ou demarcação territorial. Inácio Elói Madureira participou da expedição ao sertão do Tibagi, em 1757, poucos anos antes da nomeação como primeiro governador da capitania subalterna. Da mesma forma, José Custódio de Sá e Faria, que fora nomeado sargento-mor Engenheiro da Expedição de Limites, em 1751. Na atividade de demarcação do Tratado de Madri também participou o governador interino Antônio da Veiga de Andrade, nomeado Segundo Comissário e Astrônomo da $2^{a}$ Partida, em 1759. Outras vezes, a participação em expedições seria decorrente do próprio exercício do cargo, como foi o caso de Sebastião Xavier Cabral da Câmara, designado, em 1781, o Comissário-chefe da Demarcação de limites do Tratado de Santo Ildefonso. Essa exigência faz sentido, dado o panorama bélico da fronteira sul, que requeria ações enérgicas e conhecimento estratégico militar.

Quanto à situação conjugal, parece não ter sido impeditivo o fato de ser casado, muito embora as esposas quase nunca acompanhassem seus maridos nas remotas regiões que governavam. Dois dos governadores da ilha de Santa Catarina eram nascidos na América: Manoel Soares Coimbra nasceu no Rio de Janeiro, por volta de 1737, e Joaquim Xavier Curado, em Goiás, em 1743, e contavam com ligações entre capitanias, portanto. Os títulos e gratificações que Ihes chegaram às mãos (Hábitos da Ordem de S. Bento de Avis) viriam depois de muitos anos de serviços militares prestados em solo americano $^{71}$ e concedidos em um período (virada do Setecentos para 0 Oitocentos) no qual houve maior abertura na política de mercês. ${ }^{72}$

Se, por um lado, o posto de governador da ilha de Santa Catarina valorizava-se por ela ocupar posição estratégica fundamental em território de disputa entre as duas nações ibéricas, e tivesse se constituído, efetivamente, como importante base política e militar aos planos expansionistas da Coroa Portuguesa nesse amplo espaço platino, por outro, a subalternidade ao governo do Rio de Janeiro reduzia o status do seu cargo, o que se refletia nas posições hierárquicas inferiores tanto nobiliárquicas como militares dos seus governadores. Entretanto, em situações críticas, como o da iminente invasão espanhola da Ilha, em 1775, ou quando foi preciso restabelecer a dignidade lusitana, com a restituição dela aos domínios de Portugal, em 1778, brigadeiros e fidalgos foram chamados para exercer sua governança. Contudo, com o avançar do século XVIII, o governo de Santa Catarina foi gradativamente perdendo importância devido às mais urgentes necessidades de guerra no Rio Grande de São Pedro. Concomitantemente, essa capitania florescia

${ }^{70}$ Cf. Banco de dados Optima Pars, e PIAZZA, W. Dicionário Político..., op. cit., p. 551.

71 PIAZZA, W.. Dicionário Político..., op. cit., pp. 163 e 194; Banco de Dados Optima Pars, ARAÚJO, Pizarro. Memórias Históricas do Rio de Janeiro e das Províncias anexas à Jurisdição do vice-rei do Estado do Brasil. Rio de Janeiro: Imprensa Nacional, 1822, p. 318 e 320.

72 Ver MONTEIRO, N. G.; CUNHA, M. S. Governadores e capitães-mores..., op. cit., p. 197 e 229. De acordo com esses autores, os filhos da América enfrentavam, via de regra, dificuldades maiores que os indivíduos nascidos no reino para ascender na hierarquia social portuguesa. 
economicamente a despeito dos reveses bélicos, em especial a partir de 1777, quando um panorama de relativa paz estabeleceu-se na região. No final da centúria, a Coroa portuguesa examinava já a possibilidade de "estabelecer uma Capitania do Rio Grande de São Pedro; e Santa Catarina que seja separada das outras", o que de fato veio a acontecer em 1807, por meio de carta régia assinada pelo príncipe regente Dom João. ${ }^{73}$ A nova capitania englobava, ao menos em teoria, tanto a área de Santa Catarina quanto a do Rio Grande, mas sua capital se sediava em Porto Alegre, no território da última. A hegemonia administrativa rio-grandense sobre a ilha manifestou-se novamente em 1812 quando a sede da ouvidoria da comarca transferiu-se de Desterro igualmente a Porto Alegre, selando o reconhecimento da Coroa sobre a hierarquia políticoespacial do território meridional.

\section{Perfil social das vereanças nas Franjas do Império}

A história da Câmara da vila do Rio Grande de São Pedro é sem dúvida a mais atribulada dentre suas congêneres sulistas e a que melhor funde elementos locais e imperiais em seu desenvolvimento. Devido a sua posição geográfica (a mais meridional do Brasil no período) e ao acirramento de tensões entre Espanha e Portugal no Prata, o conselho sul rio-grandense distanciou-se do modelo bandeirante das vilas de Curitiba, Laguna e Desterro. A Coroa fez-se presente desde cedo na localidade e sua gerência aumentou com a transformação do Rio Grande de São Pedro em capitania. ${ }^{74} \mathrm{Em}$ paralelo, 0 povoamento da vila de Rio Grande não dependia de maneira tão acentuada do contingente paulista, contando com expressivo número de militares e de civis oriundos do Rio de Janeiro e da Colônia do Sacramento. A esses se somaram os casais açorianos chegados na década de 1750 e um crescente número de comerciantes reinóis que se dirigia para a vila na intenção de fazer fortuna com o comércio de gado e de couros.

A invasão espanhola à vila de Rio Grande, em 1763, traria enormes consequências, causando a debandada de sua população para a povoação de Viamão ao norte da capitania do Rio Grande de São Pedro ou mesmo para os territórios do centro do Brasil. Os oficias camarários, sem alternativa, refugiaram-se também em Viamão de onde prosseguiram a governança da república dando origem a mais de quarenta anos de anomalia administrativa: a Câmara deslocara-se da sede da vila (agora sob posse espanhola) localizandose em mera freguesia. ${ }^{75}$ Não fosse suficiente, a instituição demonstrou

\footnotetext{
${ }^{73}$ ANRJ. Carta de Dom Rodrigo de Souza Coutinho ao Conde de Rezende, 9 de dezembro de 1796. Códice 67, volume 21, folha 123.

74 "Concomitant with the founding of Rio Grande (1737), Santa Catarina was brought under more direct royal control. As part of a general administrative reorganization of Brazil, both Santa Catarina and Rio Grande were detached from São Paulo and made subcaptaincies of Rio de Janeiro. Desterro became the new capital and the headquarters of a governor, an ouvidor, and a fiscal subdivision of the parent captaincy." ALDEN, Dauril, op.cit., p. 72-73.

${ }^{75}$ As freguesias referiam-se a circunscrições eclesiásticas, ou seja, "Área territorial delimitada que tem por sede uma igreja matriz onde se registram os batizados, casamentos e óbitos. Em frente da matriz havia a praça e a partir de seus ângulos traçavam as ruas, com lotes para as
} 
verdadeira vocação itinerante sendo novamente transferida (junto com os demais aparelhos administrativos), mas não para sua locação original, à qual jamais retornaria. No ano de 1773, devido a conflitos entre facções da elite local e entre a Câmara e o governador da capitania, o conselho se trasladaria de Viamão para a incipiente povoação de Porto Alegre, que então se tornou a nova capital da capitania. A reconquista da vila de Rio Grande pelos portugueses, em 1776, não findou esse confuso cenário. Ainda que a sede da vila voltasse ao controle luso, a Câmara estava situada em outra localidade: a concorrência dos impérios ibéricos presenteava ao Rio Grande de São Pedro a peculiaridade de possuir uma Câmara deslocada da sede do termo da vila. ${ }^{76}$

Em Viamão e Porto Alegre a Câmara aparentemente manteve o perfil social que ostentou em Rio Grande. ${ }^{77}$ Nesses sítios a composição camarária mostrou-se bastante diversa do modelo das antigas famílias paulistas de Curitiba e de Laguna, apontando para um novo tipo de cidadão que se gestava na segunda metade do século XVIII, fruto das orientações econômicas do império e da nova postura da Coroa ao procurar consolidar sua posição de centro político restringindo gradativamente as autonomias camaristas. No período em que a Câmara esteve arranchada em Viamão (1763-1773), a maioria dos oficiais que se dedicou à governança da república provinha de Portugal continental; dos 27 eleitos cuja naturalidade foi identificada nesse intervalo somente 3 nasceram na América (1 na Colônia do Sacramento e 2 em Rio Grande). Rompia-se a tendência da Câmara como um refúgio de "conquistadores" ou de "principais famílias da terra". Nos primeiros vinte anos da Câmara em Porto Alegre esse dado seria confirmado, pois ao menos $40 \%$ do total de oficiais eram originários do Reino, enquanto os americanos conformavam somente $11,6 \%$. A despeito da proximidade com Laguna e da corrente migratória desta vila para os Campos de Viamão, os lagunenses e seus herdeiros ausentaram-se do conselho sul rio-grandense. Os camaristas eram migrantes chegados diretamente do Reino, desvinculados dos códigos paulistas que permeavam o funcionamento dos demais conselhos do sul. ${ }^{78}$ Os

casas". FLORES, Moacir. Dicionário de História do Brasil. Porto Alegre: EDIPUCRS, 2001, p. 265. Desta função aglutinadora da freguesia, referência central dos povoados, e reguladora, para registro da população, concluímos a importância que adquirira como sinônimo de recorte administrativo dentro da jurisdição da vila.

${ }^{76}$ Não obstante as duas mudanças de sítio, a Câmara permanecia como referente à vila de Rio Grande, ainda que a denominação documental dirija-se a seu local de assentamento, sendo usualmente chamada de Câmara de Viamão ou de Porto Alegre. A situação só se corrigiu em 1810, quando Porto Alegre se tornou oficialmente vila e Rio Grande recebeu Câmara própria. Porto Alegre compara-se a Curitiba, sendo "fundada" em diferentes etapas: a criação da freguesia em 1772, a elevação à capital da capitania e recebimento da Câmara em 1773 e criação efetiva da vila em 1810. COMISSOLI, Adriano. Os "homens bons" e a Câmara Municipal de Porto Alegre (1767-1808). Porto Alegre: Gráfica da UFRGS, 2008.

77 A perda dos livros do conselho quando da invasão espanhola de 1763 impede um estudo detalhado sobre os primeiros anos da Câmara, mas indicações esparsas confirmam certos nomes como exercendo ofícios antes e depois da transferência, dentre os quais podemos destacar Manuel Fernandes Vieira e Manuel Bento da Rocha, muito influentes na instituição. Idem, ibidem.

${ }^{78}$ KÜHN, Fábio. Op. Cit., p. 277. COMISSOLI, Adriano, op.cit., p. 66. 
curitibanos, por sua vez, eram descendentes de famílias enraizadas na América há muito tempo, "um luso-brasileiro de terceira ou quarta geração". ${ }^{79}$

A ocupação econômica dos vereadores no Rio Grande de São Pedro também divergia do padrão da "nobreza da terra" dedicada principalmente à propriedade rural. Em Viamão, do total de 36 oficiais, dispomos de dados ocupacionais para 33 sujeitos dos quais 19 (58\%) se dedicavam à atividade comercial contra 12 estancieiros (36\%). ${ }^{80}$ Em Porto Alegre, entre 1774 e 1794, de 69 oficiais 31,85\% estavam ligados ao comércio, ainda que dividissem essa atividade com alguma produção rural. Aqueles que tiveram sua atividade econômica identificada exclusivamente ao campo perfazem meros 5,8\%. ${ }^{81} \mathrm{Em}$ listagem dos elegíveis à Câmara de Porto Alegre, em 1814, os comerciantes eram ainda mais expressivos: $77,8 \%$ do total, contra apenas $14,3 \%$ dos que se ocupavam da economia agrária. ${ }^{82}$ Esses dados assumem uma proporção de maior vulto contrastados ao fato de ser o Rio Grande de São Pedro uma sociedade marcadamente rural, cuja maior riqueza assentava na criação de animais para transporte e produção de charque. Na Câmara, entretanto, a primazia estava nas mãos dos comerciantes, responsáveis que eram por fechar o circuito comercial dos criadores de animais com os mercados do centro do Brasil, uma função que assumia vulto com o crescimento da economia sul riograndense ao final do setecentos. ${ }^{83}$

A Câmara trasladada de Rio Grande desenhava um novo perfil de oficial, mais apropriado ao século XVIII e que rompia com o modelo tradicional das "principais famílias da terra". O português migrante e comerciante era o camarista do extremo sul, em consonância com os tempos em que vivia. Nas cidades do Rio de Janeiro e do Recife, ambas muito mais ao norte, a primazia dos comerciantes naturais do Reino também se consolidava no século XVIII e início do século XIX. O antigo conquistador armado e realizador de bravos feitos em nome de seu rei via-se suplantado pelos mercadores lusitanos em Câmaras do norte e do sul da América portuguesa. As redes de relações que permitiam o fluxo constante de migrantes lusitanos para o extremo sul do Brasil possibilitava-lhes ainda a acolhida na comunidade mercantil, a inserção nesse ramo de atividade e, posteriormente, o ingresso na instituição camarária. ${ }^{84} \mathrm{E}$ nesse cenário saíam fortalecidos os governadores nomeados pelo rei, visto que passavam a tutelar e suplantar as autonomias locais.

A Câmara do Rio Grande de São Pedro percebia sua autonomia muito mais delimitada pela Coroa do que Curitiba ou Laguna tiveram até meados do XVIII. Na passagem da década de 1770 para a de 1780, o conselho deixou de se envolver em assuntos de escopo monárquico para restringir sua atuação ao

\footnotetext{
${ }^{79}$ PEREIRA, Magnus Roberto de Mello; SANTOS, Antônio Cesar de Almeida. Op. Cit., p. 28.

${ }^{80}$ KÜHN, Fábio, op.cit., p. 279.

${ }^{81}$ Contudo permanecessem desconhecidas as ocupações da maioria dos vereadores, cerca de 60\%. COMISSOLI, Adriano. Op. Cit., p. 68.

82 OSÓRIO, Helen. Estancieiros, Lavradores e Comerciantes na Constituição da Estremadura Portuguesa na América: Rio Grande de São Pedro, 1737 - 1822. Niterói: Tese de Doutorado, PPG em História da Universidade Federal Fluminense, 1999, p. 255, nota 15.

83 Ibidem. Cap. 9; HAMEISTER, Martha Daisson, op.cit., p. 234-235.

${ }^{84}$ COMISSOLI, Adriano, op.cit, p. 73.
} 
plano local. ${ }^{85}$ Contudo, as três possuíam uma condição comum, em todos os casos havia sido assinalada para esses conselhos uma jurisdição de proporções imensas que, na prática, dificilmente poderia ser atendida. Em Portugal continental a área dos municípios variava bastante indo de médias de $49 \mathrm{~km}^{2}$, no Minho, a $333,3 \mathrm{~km}^{2}$, no Algarve, em princípios do século XIX, enquanto as distâncias nas franjas da monarquia lusitana mostravam-se muito superiores. ${ }^{86}$ Curitiba, quando criada, confrontava ao norte com Sorocaba e a leste com a vila de Paranaguá, tendo a oeste e ao sul um limite indefinido. De fato, o alcance da vila seria tão amplo quanto 0 avanço da povoação permitisse. ${ }^{87}$ Laguna herdaria essa indefinição em direção ao sul sendo responsável pelas justiças de todo Continente de São Pedro até a criação da vila de Rio Grande, em 1747, uma área de milhares de quilômetros quadrados. Rio Grande, em sua carta de criação, teve assinalado seu termo como confrontando tanto Laguna, pelo litoral, quanto Curitiba, pelo sertão, uma distância de cerca de mil quilômetros entre as sedes das duas vilas. ${ }^{88}$

A criação na região do planalto catarinense da vila de Lages (1766), por ordem do Governador de São Paulo, Dom Luís Antonio de Souza Botelho Mourão, o Morgado de Mateus, visava otimizar a administração local por meio do fracionamento dessa ampla área, mas terminou por suscitar a indignação dos camaristas de Viamão. Sua queixa referia-se à perda de rendimentos que seguiria a diminuição territorial e populacional, o que indica que, apesar da distância, existia algum grau de controle sobre o planalto, apesar de ele se configurar por povoações pouco expressivas. ${ }^{89}$

As Câmaras litorâneas possuíam áreas menores, visto que a distância entre Laguna e Desterro e desta até São Francisco era de cerca de uma centena ou duas de quilômetros. Ademais, a delimitação do planalto como pertencendo às jurisdições de Curitiba, Rio Grande e, mais tarde, Lages indica que as três vilas litorâneas não controlavam a serra, apesar da proximidade espacial, limitando-se ao controle imediato nas terras entre o mar e as encostas dos montes. A jurisdição catarinense aproximava-se da configuração da vila de Santos na capitania de São Paulo, restrita ao litoral.

A criação de uma vila de mesmo nome na baía de Garatuba (entre a de Paranaguá e a de São Francisco do Sul) visou ao preenchimento administrativo das regiões ocupadas por luso-brasileiros, como ocorrera no planalto. A nova vila era também criada por ordem do Morgado de Mateus, que executava uma política de aumento da malha administrativa local nos territórios por ele governados. Como no caso de Lages, o surgimento de nova vila por consequente desmembramento da jurisdição de outra mais antiga suscitou insatisfação, dessa vez dos camaristas de São Francisco do Sul, que contestavam a jurisdição de São Paulo na região. Guaratuba, ao contrário de

\footnotetext{
${ }^{85} \mathrm{Idem}$.

${ }^{86}$ MONTEIRO, Nuno Gonçalo, op.cit., p.. 306.

87 PEREIRA, Magnus Roberto de Mello; SANTOS, Antônio Cesar de Almeida, op.cit., p. 28.

${ }^{88}$ ANRJ. Provisão mandando criar a vila do Rio Grande, 17 de julho de 1747, códice 952, vol. 34, fl. 17.

${ }^{89}$ Termo de vereança de $1^{\circ}$ de janeiro de 1767, in. Boletim Municipal, vol. III, n. 7, jan./abr. 1941, p.69-71.
} 
outras, teve sua fundação e ereção toda guiada sob a batuta do governador de São Paulo. A intenção de povoar o sítio em questão manifestara-se em 1765 por meio de carta do próprio Botelho Mourão e a povoação já seria elevada à vila em 1771. A justificativa para o seu estabelecimento fundava-se em dois critérios: a posição estratégica de porto fluvial e a proximidade com as Minas do Ouro. Assistia-se agora a um novo padrão de instituição dos poderes locais, uma vez que o poder central tutelava por meio de um de seus agentes todo o processo de povoamento, de estabelecimento espacial e de ordenamento jurídico visando não apenas incorporar vilarejos dispersos ao complexo imperial, mas regrar novas povoações de acordo com seus interesses. ${ }^{90} \mathrm{Em}$ contraste ao crescimento numérico das vilas paulistas na segunda metade do século XVIII, percebe-se ainda que as capitanias de Santa Catarina e do Rio Grande de São Pedro (que se reportavam ao Rio de Janeiro) não receberam novas vilas até o século XIX. Dessa forma, enquanto o Morgado de Mateus multiplicava esses palcos políticos, os vice-reis Marquês do Lavradio, Luís de Vasconcelos e Souza e Conde de Resende não atuaram no mesmo sentido sobre a área mais contestada das terras disputadas, o que acusa a grande incerteza que pairava sobre o destino da região.

${ }^{90}$ DERNTL, Maria Fernanda. Uma vila ao serviço régio: a criação de Guaratuba, na capitania de São Paulo, sob o Morgado de Mateus. Anais do XXIV Simpósio Nacional de História. São Leopoldo: Unisinos, 2007, p. 3-4. 